\title{
State Nationality and Religious Family Law: Some Notes
}

\author{
A. V. M. Struycken ${ }^{1}$ \\ Published online: 30 November 2018 \\ (C) The Author(s) 2018
}

\begin{abstract}
Most States are 'secular' States. Freedom of religion allows religious communities to organize themselves within the framework of the law of the State. In some other States organized religion has a dominant position enabling it to have a major impact on the law of the State. Private International Law (PIL) of secular States is characterized by a large extent of openness to the law of other States. The extrovert character is missing on the side of non-secular States. The difference should not pass unnoticed. Nationality loses attractiveness as a connecting factor in family law, though it persists as a pointer to the cultural frame of reference for many persons. In Western countries this development is enhanced by libertarian ideas on family law. In PIL a parallel development can be registered. The scope of conflicts of laws rules tends to lose effect on the recognition of acts and facts that are situated abroad. This new 'method of recognition' appears to have some effect on the case law of superior courts. The European Union has had to deal with recognition issues in the field of family law.
\end{abstract}

Keywords Religious family law Private international law $\cdot$ Method of recognition Nationality · Islamic law

\section{State and Religious Family Law}

This is an issue with a history. Many States, since more than two centuries, have adhered to the principle of separation of State and Church. Before that time, during many centuries, there was a tension between secular and religious authorities. Emperors claimed supreme authority on religious matters. One emperor, Constantine the Great, decided to convene the first ecumenical Council in the fourth century, Nicaea $325 .{ }^{1}$ But Charlemagne went to Rome to be crowned emperor by Pope Leo III in 800. Otto I, first emperor of the Holy Roman Empire, did likewise: he was crowned by Pope John XII in 962. Pope Pius VII went to Paris at least with the

\footnotetext{
A. V. M. Struycken teun@struycken.co.nl

$1 \quad$ Heilig Landstichting, The Netherlands
}

1 Vermes (2012), pp. 223 et seq.; Ware (2015), pp. 18 et seq. 
intention of crowning Napoleon emperor in 1804. Between these periods, the investiture - the right to nominate bishops- had been a hot issue in the twelfth century and popes and emperors, for instance Frederick Barbarossa and Frederick II, had not very peacefully fought over this. ${ }^{2}$ In the Netherlands, in the early 19 th century, King William I felt that as a sovereign he could interfere in church matters. It furthered the secession of the largely catholic Belgium in 1831 .

Freedom of religion equally has been the outcome of a long history. In the seventeenth century, in the German kingdoms and principalities, the prince's religion also held for his people, cuius regio illius et religio. Freedom of religion found its expression in the Déclaration des droits de l'homme et du citoyen, Article X, of August 1789, and in the US Constitution, 1st Amendment, of December 1791.

States that adhere to the principle of separation of State and Church, hereinafter: secular States, will not readily accept the idea of a system of religious law. Religious communities may have their own regulations and organization, but in the system of State law of those States, those communities resemble private law associations which benefit from the fundamental right of freedom of religion.

Other States have strong links with at least one single religious community. They have a State religion, e.g. Greece-and before Greece obtained political independence in 1821, the Ottoman Empire-, England, Sweden, Russia, ${ }^{3}$ Israel, Islamic States.

To varying degrees, civil authorities exercise powers and interfere in religious matters and, the other way around, religious authorities feel free to impose their views. Some States have a body of religious law that has a prominent place in their constitutional order.

\section{Some Religious Communities Have a Long History}

In addition to a long history, those communities have spread far beyond the borders of modern States and have their own firmly established bodies of law. ${ }^{4}$

Jewish law has a very long history ${ }^{5}$ and it now has a central place in Israel. Its Rabbinical Courts Jurisdiction (Marriage and Divorce) Law, 5713-1953, first section, provides that 'matters relating to marriage and divorce of Jewish citizens or residents of the State of Israel shall be within the sole jurisdiction of the Rabbinical Courts'. The law to be applied in these matters is the law of Torah. ${ }^{6}$

The Roman Catholic Church has its 'canon' law, which reaches back to the Decretum Gratiani 1139 and far beyond (see praefatio CIC). It is now mainly

\footnotetext{
${ }^{2}$ Crul (2017), pp. 30-38.

3 Ware (2015), pp. 140 et seq.

4 Caparros and Christians (2000); for the Netherlands: Struycken (2000), pp. 417-438; Hamilton (1995), mainly for UK and US.

5 See Hecht et al. (1996).

6 Sinclair (1996), p. 400; Gaudemet-Tallon (2005), no. 187.
} 
contained in the Codex Iuris Canonici 1983. ${ }^{7}$ This code (CIC) in 1990 obtained a parallel Code of Canon Law for the Eastern Churches (CCEO), i.e. the twenty-one orthodox churches united with Rome.

Canon law has a wider scope than family law only. After the reception of Roman law in the Renaissance, canon law had a major impact on the development of that new Roman law. Contract law gradually recognized that mere consensus is binding-nudus consensus obligat. This has a canon law origin. In the field of marriage, canon law had a great impact in many regions until the French Revolution, and still has in some countries. ${ }^{8}$

Islamic States are Islamic to the large extent they adhere to the Sharia. The Sharia goes back to the era of the Prophet, the seventh century, and so dates from long before the modern Islamic States came into existence.

\section{Modern States Each Have Their Own Private International Law (PIL), Rather Extrovert}

If the circumstances of a case so suggest, modern States-their courts and other authorities - are willing to apply foreign law. They may do so according to rules which provide for a connecting factor that reflects a meaningful connection with some law. In many States, the PIL system provides for determining the applicable law along the lines of the doctrine of Friedrich Carl von Savigny (1849) in accordance with bilateral conflict rules. This does not exclude, in exceptional cases, the public policy device for the protection of fundamental values.

In secular States, PIL starts from the idea that States have much in common and constitute some sort of community of common concepts and principles which make their systems of private law comparable. In that respect they are equal and exchangeable. A prominent concern of each system of PIL is to find a balanced 'coordination' with foreign systems. This concern was emphasized by, among others, Henri Batiffol, ${ }^{9}$ who inspired many after him.

Von Savigny, in his System des heutigen Römischen Rechts, referred to a public international law community of the nations which have relations with each other. ${ }^{10}$ One should not overlook the particle ' $a$ '. He did not mean the public international law as a system of positive law as it has developed mainly since 1849 when this part of his book was published. In the same paragraph, sixty lines below, he refers to 'the possible, desirable, to be looked forward to, public international law community in the dealing with conflicts of local laws' and underlines that treaties to that effect

\footnotetext{
7 Neuhaus (1983), pp. 502 et seq.; Neuhaus (1966), pp. 40-53; Wengler (1991), pp. 26-28.

8 Gaudemet-Tallon (2005), nos. 188, 452.

9 Batiffol (1956).

10 Von Savigny (1849), para. 348: ‘...Der Standpunkt, auf den wir durch die Erwägung geführt werden, ist der einer völkerrechtlichen Gemeinschaft der mit einander verkehrenden Nationen, und dieser Standpunkt hat im Fortschritt der Zeit immer allgemeinere Anerkennung gefunden, unter dem Einfluss theils der gemeinsamen christlichen Gesittung, theils des wahren Vortheils, der daraus für alle Theile hervorgeht.'
} 
between different, in particular neighboring States, would be particularly helpful in promoting the principles he had drafted. ${ }^{11}$ Those State systems are characterized by openness to the outside world; they are extrovert.

Application of foreign law is not a simple task, but is not understood as undue interference in the competence of the courts of the foreign law concerned. Foreign courts do not claim exclusive competence for the application of their own law and, vice versa, the forum courts do not claim exclusive competence as to the application over their own domestic law. The courts' concern is to do justice in the case at hand.

\section{Systems of Religious Law are, on the Contrary, Rather Introvert}

PIL questions with which secular State courts are confronted, hardly arise for religious authorities. For them the connecting factor is membership of the religious community regardless of nationality or habitual residence. For them, also, the close link of their law to the underlying religion makes it evident that they have exclusive jurisdiction. Only they are qualified to give orthodox judgments. ${ }^{12}$ Coordination of systems of PIL as underlying the Savinian ${ }^{13}$ approach is not their concern.

For Islam, the separation of politics and religion does not exist: the believers merge in one community, the 'Umma'. God is its legislator and dictated his will in the Coran, which is final and eternal. There is no room for a law other than the Sharia. The claim of applicability of Islam law even extends to cases where only one of the parties is Islamic. ${ }^{14}$ There is no room for courts other than Sharia courts. ${ }^{15}$ Islamic countries stick to the Islamic faith as connecting factor in matters of family law. Nationality of an Islamic country as connecting factor is just a camouflage. ${ }^{16}$ Their approach is unilateralist.

The basic difference between secular States, on the one hand, and the States closely linked with a religious community such as Islamic States that find their inspiration in the Sharia and loyally adhere to it, on the other hand, and the related consequences for PIL were described in much detail by Léna Gannagé ${ }^{17}$ and Yves Lequette. $^{18,19}$

\footnotetext{
11 Ibidem: 'Die hier aufgestellten Grundsätze über die mögliche, wünschenswerthe, zu erwartende völkerrechtliche Gemeinschaft in der Behandlung der Collisionen örtlicher Rechte können eine besondere Förderung erhalten, wenn über diesen Gegenstand unter verschiedenen, besonders unter benachbarten Staaten, bei welchen die Collisionsfälle am häufigsten eintreten, Staatsverträge geschlossen werden.'

12 Gannagé (2013), pp. 223 et seq., no. 8, building on her widely known thesis, Gannagé (2001).

13 Struycken (2009), no. 181, fn. 436: savinian rather than savignyan.

14 Gannagé (2013), nos. 50, 53, 57, 63, 70; Lequette (2017), no. 210; Gaudemet-Tallon (2005), nos. 185, 454.

15 Gannagé (2013), no. 82.

16 Lequette (2017), no. 210, agreeing with a quote of J. Deprez; Gaudemet-Tallon (2005), no. 454.

17 Gannagé (2013), nos. 49, 50, 57; Gannagé (2008b) pp. 285-293.

18 Lequette (2017), nos. 197-203.

19 Gannagé and Lequette build on earlier studies, see Lequette (2017), fn. 1163, several of which were published in the Collected Courses of the Hague Academy of International Law. See in particular, Najm (2005). See also: Foblets and Yassari (2013); Kruiniger (2014); Jayme (1995), pp. 52-53, and fnn. 85 and 86; Siehr (2004), pp. 325-340 (326-332); Malatesta (2009), pp. 643-657.
} 
For PIL systems of secular States there is a risk of excessive generalization of the traditional PIL approach described above insofar as they tend to ignore a 'conflict of civilizations' signaled by the said authors. ${ }^{20}$ They may automatically refer to the Savinian approach and the Western coordination of systems. Gannagé and Lequette, referring to extensive documentation, emphasize that Islamic States do not participate in such a rather Western community. ${ }^{21}$ The Western approach based on the presumption of exchangeability does not work, or at least it works to a very limited extent. This is a welcome diversification of the traditional perspective.

The Resolution adopted by the Institut de Droit International (IDI) during their Cracow Session of 2005 contains an appeal addressed to States adhering to their system of religious law to show some flexibility. ${ }^{22}$ It notes that 'the opposition between various cultures is a consequence especially of the conflict between secular and religious doctrines' and considers that 'the systematic reciprocal exclusion of laws from different countries by the invocation of public policy fails to take into account the need to coordinate legal systems'. It states as one of some general principles:

States shall avoid using religion as a connecting factor for the purpose of determining the law applicable to the personal status of foreigners. They should make it possible for the latter to choose between their national law and the law of their domicile in cases where the State of nationality and the State of domicile differ.

The Resolution is a serious effort by the IDI to bring about some conciliation between quite different approaches.

\section{Nationality/Citizenship as Connecting Factor}

For matters of family law, those connecting factors have lost much of their attractiveness in Western countries. Nationality as the connecting factor for matters of family law has had a stronghold in the French Code civil. The third paragraph of Article 3 reads: 'Les lois concernant l'état et la capacité des personnes régissent les Français, même résidant en pays étranger.' ${ }^{23}$ The French Code has had a major impact on the codification of private law in many 'civil law' countries. That particularly applies to its Article 3. It has been read gradually as a bilateral conflict rule: matters of family law are governed by the national law of the persons concerned. The doctrine of P.S. Mancini in the second half of the nineteenth century is considered to have reinforced the support for the connecting factor nationality. ${ }^{24}$ In the early conventions

\footnotetext{
20 Gannagé (2013), nos. 301-342; Lequette (2017), nos. 209-214.

21 See, recently, on von Savigny: Symeonides (2017), pp. 48-52.

22 Annuaire de l'Institut de Droit International, Session de Cracovie, Vol. 71-II, Pedone, Paris (2006), pp. 290-295 (French and English versions), rapporteur Paul Lagarde, minutes plenary discussion pp. 139-197. Report P. Lagarde, Vol. 71-I (2005), pp. 13-115.

23 In some recent editions of the Civil Code by Dalloz: 'pays étrangers' plural! Error!.

24 Nishitani (2000), §5 I Das Prinzip der 'nazionalitá', pp. 48-57.
} 
of the Hague Conference on family law matters it was by far the main connecting factor, even for matrimonial property. Problems arose when the unity of nationality of married couples was no longer self-evident. Increasing respect of the equality of sexes may have played a role where statutes on nationality in several States no longer adhered to the principle that a wife had to follow the nationality of the husband, even by operation of law. What law governs divorce if spouses have different nationalities? The French Cour de cassation, in its judgment of 17 April 1953 in the Rivière case, held that such a divorce was governed by the law of the 'domicile commun'. ${ }^{25}$ The decision had a major impact, far beyond the French borders. Step by step, nationality has lost terrain as a connecting factor. This has not withheld the European Court of Human Rights from stating recently that nationality is an element of a person's identity. ${ }^{26}$

Habitual residence tends to replace nationality. In the present year 2018 one has become much aware of the dubious expectations of the degree of integration of foreigners, immigrants and expats in the country where they have lived for some time. It is not quite sure that a policy of simplifying the acquirement of a passport as evidence of a new nationality has been and is an effective tool for furthering integration.

The present writer may quote the opinion he expressed in 2009 as he has found no evidence of change of society since that year:

[E]qual treatment under the law of the common habitual residence may constitute 'discrimination' as well-be it not discrimination on the basis of nationality as proscribed by Article 12 EC but nevertheless discrimination-as the family relationships may be very different, 'unequal', because of the different national and cultural backgrounds of the people concerned. Cypriot, Finnish, Spanish and Polish families may live in The Hague in the same street for years, as 'expats' (expatriates) or under whatever other title, or non-title, of residence, without knowing more than one hundred words of Dutch to the extent necessary to survive shopping expeditions and without integrating really in Dutch society more than at the level of the football club of the children. There is a lot of phantasy about social integration in the society of the habitual residence, the more so where there is tendency to be not too severe on the requirement of 'habitual' residence. [...] The State of the habitual residence does not necessarily provide the genuine cultural frame of reference for the people concerned. $^{27}$

A side product of the Olympic Games and of comparable events is that they reveal the real sense among the public of belonging to a nation, of loyalty to a nation even, be it without the necessity of paying a price for the choice expressed.

\footnotetext{
${ }^{25}$ Revue critique de droit international privé 1953, case note Henri Batiffol; RabelsZ 1955, p. 520, case note $\mathrm{Ph}$. Francescakis; Ancel and Lequette (2006), no. 26.

26 ECtHR Mennesson v. France, Application no. 65192/11, 26 June 2014, para. 91, and Genovese v. Malta, Application no. 53124/09, 11 October 2011, para. 33.

27 Struycken (2009), no. 142. See also nos. 284, 287, 289; and Gaudemet-Tallon (2005), nos. 185, 192.
} 
Whatever one may think about integration of Chinese, Indian, Vietnamese and other immigrants in a Western European country, the cultural frame of reference of immigrants from Northern Africa, the Middle East and Turkey, and other Islamic countries does not leave much doubt, and probably the other way around: integration of Westerners in those countries. The Hague Convention on the Law Applicable to Succession to the Estates of Deceased Persons 1989 was brought about after several hot discussions, one of which resulted in an escape clause in its Article 3, paragraph 2: the connecting factor of 5 years of residence in the country of habitual residence was unacceptable to some delegates, taking into account the following example: imagine an English engineer who has been working in Saudi Arabia in the oil industry for 6 years is killed in a traffic accident. To make sure that common law on succession, as his national law, would apply, an escape clause was consented to, in order to avoid that 'in exceptional circumstances' Arabian law would be applicable. ${ }^{28}$ The escape clause has not contributed to the required certainty and may explain, to some extent, the lack of success of the Convention.

In the delicate field of law and religion, Lebanon managed to find adequate solutions. National law applies to Lebanese citizens, but that means that one is referred by that Lebanese national law to the religious law of one of the numerous religious communities. Civil law marriage has not been provided for, but a civil marriage celebrated in a foreign country by Lebanese citizens is recognized. ${ }^{29}$

\section{Developments in Domestic Law of Western Countries}

The developments in domestic law in Western countries should not be neglected as a factor of impact in an overview of international family law relations, especially in connection with Islamic law. Those developments may explain to some extent that Western countries have lost their priority for nationality/citizenship as connecting factor.

Professor Léna Gannagé notes a fundamental transformation in Western Europe of the ideas about family and marriage. There has grown a pluralism of family models, which is due to an individualism favored by the European Court of Human Rights. Same sex marriage, partnership, easy divorce, and diverging concepts of parent child relationships have spread in quite numerous Western countries. The family is no longer an institution the State takes much care of. ${ }^{30}$ Professor Lequette takes the same view. ${ }^{31}$ Added to this is the tolerance with regard to abortion and euthanasia. Both speak of a chasm, an abyss, between Western and Islamic countries, as a consequence of this recently grown state of Western family law. The libertarian ideas prevailing in the West which enjoy wide political support are not helpful in reaching agreement with Islamic countries.

\footnotetext{
28 Struycken (2009), no. 322.

29 Najm (2005), nos. 558-636; Gaudemet-Tallon (2005), no. 189.

30 Gannagé (2013), nos. 302-310.

31 Lequette (2017), nos. 214, 340-352.
} 


\section{Conclusions from the Explorations by Gannagé and Lequette}

The distinguished writers do not avoid presenting conclusions from their explorations. Professor Gannagé does not conceal that her optimism is very moderate, see the general conclusion of her Academy lectures, published in 2013. ${ }^{32}$ Professor Lequette, fully aware of the different approaches, does not show more optimism in 2017. The large theme of his rich General Course leads to far-reaching conclusions that are not limited to the religious law issue and reflect no more optimism. ${ }^{33}$

\section{In Legal Science One Should Not Resign}

In PIL science one should not resign at this new development but try to find an adequate approach to PIL problems arising from relationships with Islamic countries. The IDI made an effort in 2005, mentioned above in Sect. 4.

One could try to explore the outcome of a recent general PIL theory, the 'method of reconnaissance of established legal situations', i.e. a method involving recognition of facts that have taken place abroad according to the local PIL system. A great authority like Professor Paul Lagarde, winner of the Hague Prize of International Law 2011, expressly adheres to this method. ${ }^{34}$ The final sentence of his Academy lecture reads: 'La méthode du conflit de lois a toute sa place au stade de la création des situations. Une fois celles-ci créées, la place doit être laissée à la méthode de reconnaissance.' [The method of the conflict of laws has fully its place at the stage of the creation of the situations. Once those situations created, the place should be left to the method of recognition.] The method has mobilized many writers of great reputation, mentioned in the Academy lecture. ${ }^{35}$

The present writer expressed some doubts. ${ }^{36}$ In the country where the recognition might be requested, it is up to the local courts to determine what is the law in that country concerning the issue presented. Such an outcome may be undermined by the claimed recognition of a different legal outcome on the same issue resulting from some foreign determination. Equality before the law might be endangered.

\footnotetext{
32 Gannagé (2013), nos. 336-341.

${ }^{33}$ Lequette (2017), nos. 203, 395-400.

${ }^{34}$ Lagarde (2013); Lagarde (2015), pp. 19-42; Lequette (2017); nos. 353-372.

35 See Lagarde (2015), fn. 1; Lequette (2017), nos. 353 et seq.; Vonken et al. (2016), no. 351 (Asser/ Vonken 10-II 2016/351).

${ }^{36}$ Struycken (2009), nos. 444, 452, 545-547. See also Sonnenberger (2010), pp. 371-391.
} 


\section{The New Method and the European Court of Human Rights}

The new method received a stimulus from the case law of the European Court of Human Rights (Council of Europe, Strasbourg, ECtHR) and of the Court of Justice of the European Union (ECJ, Luxembourg). The Courts largely agree on human rights issues. $^{37}$

The European Convention on Human Rights and Fundamental Freedoms, Rome 1950, as amended since and supplemented by a series of Protocols (ECHR), is the field of operation of the ECtHR. The Court has had to deal with an increasing number of cases, to be counted by the thousands. Some judgments interfere in PIL family matters and tend to disturb the traditional PIL approach, including nationality as the connecting factor. ${ }^{38}$ They favor, however, the new PIL method of recognition of situations that have come into being abroad. ${ }^{39}$

The ECtHR gave a judgment on 20 July 2001 in Pellegrini v. Italy. ${ }^{40}$ The underlying problem was the annulment by an ecclesiastical court, the Roman Rota, of a marriage. The annulment judgment was presented to an Italian court for recognition in conformity with the Concordat between Italy and the Vatican as amended by agreement of 1984. The ECtHR disagreed with the Italian Corte di cassazione. Italy had violated Article 6 of the Convention as it had overlooked that in the ecclesiastical procedure the assistance of a lawyer to the defendant, the wife, had been substandard.

Mary Green, a citizen of Malta, had married in the Catholic Church in 1978 according to the Catholic rite. Apparently, the celebration of marriage according to the Catholic rite has civil effect. She emigrated to Libya in 1980 where she converted to Islam. This conversion meant, according to the Islamic doctrine prevailing in Libya, the end of the Maltese marriage. In Libya she was authorized to marry a Mr Ajad Farhat in an Islamic ceremony. In 2000 the Islamic couple went to Malta. The Maltese authorities did not recognize the validity of their marriage. The ECtHR, in Mary Green and Ajad Farhat v. Malta, ${ }^{41}$ found that the requirements of Maltese law on marriage fell within the sphere of the respondent's State public policy, and it cannot be said that the national authorities exceeded their margin of appreciation either in imposing the requirements or in applying them in the applicants' case. No violation of the ECHR had taken place according to the ECtHR. Malta was free to adhere to its PIL rules. No trace of application of the method of recognition is found.

On 3 May 2011 the ECtHR gave a judgment in Negropontis-Giannisis $v$. Greece. $^{42}$ The issue was whether Greece violated the ECHR by the refusal to

\footnotetext{
37 ECtHR Avotins v. Latvia, Application no. 17502/0723, May 2016, paras. 102 and 70, with a nuance para. 113; ECtHR Bosphorus v. Ticaret, Application no. 45036/98, 30 June 2005, paras. 160-165.

38 Kinsch (2005), pp. 9-331; Kinsch (2004), pp. 197-228; Beaumont (2008), pp. 9-104; Struycken (2009), no. 221.

39 The discussion of the relative value of regional lists of human rights is here left side. L. Gannagé (2008a); Lequette (2017), pp. 225-235; Bucher (2009), no. 233.

40 ECtHR Pellegrini v. Italy, Application no. 30882/96, 20 July 2001.

41 ECtHR Mary Green and Ajad Farhat v. Malta, Application no. 38797/07, 6 July 2010.

42 ECtHR Negropontis-Giannisis v. Greece, Application no. 56759/08, 3 May 2011.
} 
recognize an adoption judgment rendered by a court in Michigan, USA. The adopter was a Greek monk who happened to be a bishop of the Greek-Orthodox Church in Detroit, the adoptee was a nephew of his. When the bishop had passed away, the nephew claimed to be entitled to the succession. This was contested by other members of the family. As some assets were situated in Greece, Greek courts were competent. The full Supreme Court of Greece found that the adoption was not to be recognized as such recognition was contrary to Greek public policy. Very old canons of the Church, so Greek national law, were considered to be an insurmountable obstacle to recognizing an adoption by a monk. The ECtHR disagreed as family life that had existed between the bishop monk and the adoptee (Article 8) and non-discrimination (Article 14) had to prevail. Greece had violated the ECHR.

ECtHR 4 October 2012, Harroudj v. France, deals with kafala. ${ }^{43}$ A French lady, in charge of an Algerian kafala, i.e. kafala according to Islamic law, for an abandoned Algerian child, was refused adoption in France. France was not considered to have violated Article 8 ECHR which imposes respect of family life.

More cases could be mentioned where the ECtHR had to deal with PIL issues but there is no trace of religious law, e.g. Henry Kismoun v. France ${ }^{44}$ on an administrative refusal of name change, and three cases on surrogacy: Mennesson v. France, ${ }^{45}$ Labassee $^{46}$ and D. and others v. Belgium. ${ }^{47}$

\section{European Union Law}

The EU case law should be understood in relation to the background of EC/EU legislation programmes, notably case law in the field of family names. The Action Plan of the Council and the Commission on how best to implement the provisions of the Treaty of Amsterdam on an area of freedom, security and justice (Vienna Plan 1998) had a follow-up in the Tampere Programme 1999 for 2000-2004. Its paragraph 33 states that 'the principle of mutual recognition should be the cornerstone of judicial co-operation in the Union both in civil and in criminal affairs'; it should apply to judgments and other judicial decisions. That could further the method of recognition of which Paul Lagarde is the protagonist.

The Tampere Programme was followed by the Hague Programme 2005-2009, adopted by the European Council on $4-5$ November $2004,{ }^{48}$ and the Hague Programme by the Stockholm Programme 2010-2014, adopted by the Council on 11 December 2009. One of the items of the latter programme was summarized as follows: 'a Europe of law and justice: priority should be given to mechanisms that facilitate access to justice, so that people can enforce their rights, i.e. by eliminating

${ }^{43}$ ECtHR Harroudj v. France, Application no. 43631/09, 4 October 2012.

${ }^{44}$ ECtHR Henry Kismoun v. France, Application no. 32265/10, 5 December 2013.

${ }^{45}$ ECtHR Mennesson v. France, Application no. 65192/11, 26 June 2014.

${ }^{46}$ ECtHR Labassee, Application no. 65041/11, 26 June 2014.

${ }^{47}$ ECtHR D. and others v. Belgium, Application no. 29176/13, 8 July 2015.

${ }^{48}$ Struycken (2009), no. 144. 
barriers to the recognition of legal decisions in other Member States'. After the Stockholm Programme no similar programme was adopted.

Unification of PIL at EU level looks good but one should keep in mind that EC/ EU legislation in the field of PIL does not necessarily have the primary purpose of improving PIL for itself. PIL legislation is a possible tool for realizing other purposes. ${ }^{49}$ Free movement of people [Article 18(1) EC, now Article 21(1) Treaty on the Functioning of the European Union (TFEU)] is one of the principles of the EU. It would be enhanced by a clear uniform PIL regime of names and first names. That could have been a sufficient motive to derogate from a principle, which is in line with the recent judgment in the Coman case, according to which:

37. [...] a person's status [...] is a matter that falls within the competence of the Member States and EU law does not detract from that competence [...]; [...].

38. Nevertheless, it is well established case-law that, in exercising that competence, Member States must comply with EU law, in particular the Treaty provisions on the freedom conferred on all Union citizens to move and reside in the territory of the Member States $[\ldots]^{50}$

Keeping this in mind, the Court (Grand Chamber) in Grunkin and Paul ${ }^{51}$ could have referred to the rules of the C.I.E.C. ${ }^{52}$ Convention of Munich of 5 September 1980 as sound EU rules and could have avoided the complicated situation created by that judgment. ${ }^{53}$ The main rule of the Munich Convention is that the name of a person is governed by the national law concerned, including its PIL. National law may refer to religious law, e.g. where the rule is/was that a newborn child receives its first name at baptism.

The EU is rather poor as to religious values. ${ }^{54}$ So, the law of religious communities has a minor position in the EU. An explanation is to be found in the TFEU, Article 17:

1. The Union respects and does not prejudice the status under national law of churches and religious associations or communities in the Member States.

2. The Union equally respects the status under national law of philosophical and non-confessional organisations.

\footnotetext{
49 Struycken (2009), no. 132.

50 ECJ Grand Chamber 5 June 2018, Case C-673/16, Coman, ECLI:EU:C:2018:385.

51 ECJ Grand Chamber 14 October 2008, Case C-353/06, Grunkin and Paul, ECLI:EU:C:2008:559.

52 C.I.E.C.: Commission Internationale de l'Etat Civil/International Commission on Civil Status. The Convention is ignored by Jault-Seseke and Pataut (2018), pp. 371-384.

53 ECLI:EU:C:2008:559. See ECJ 2 October 2003, Case C-148/02, Garcia v. Avello, ECLI:EU:C:2003:539 and later judgments mentioned in ECJ 8 June 2017, Case C-541/15, Freitag, ECLI:EU:C:2017:432, paras. 33 and 35; Struycken (2009), nos. 303-304. See on Art. 8 ECHR Bucher (2009), nos. 232-235.

54 Struycken (2009), no. 27.
} 
3. Recognising their identity and their specific contribution, the Union shall maintain an open, transparent and regular dialogue with these churches and organisations.

Nevertheless, this principle of non-interference which is derogated from in Directive 2000/78/EC of 27 November 2000 establishing a general framework for equal treatment in employment and occupation. ${ }^{55}$ It is worth mentioning as it refers to church law in its Article 4 and some recitals:

2. Member States may maintain national legislation in force at the date of adoption of this Directive or provide for future legislation incorporating national practices existing at the date of adoption of this Directive pursuant to which, in the case of occupational activities within churches and other public and private organisations the ethos of which is based on religion or belief, a difference of treatment based on a person's religion shall not constitute discrimination where, by reason of the nature of these activities or of the context in which they are carried out, a person's religion or belief constitute a genuine, legitimate and justified occupational requirement, having regard of the organisation's ethos.

See below, Sect. 13, for case-law of the European Court of Justice, some on this Directive.

\section{Migration}

Migration takes place on a much larger scale than in the past. Many millions of people find reasons to leave their country of origin and establish a home elsewhere or try to do so, many originating from Islamic countries.

Some are refugees in the sense of the Refugee Convention of the UN, Geneva, 28 July 1951, as extended by Protocol, New York, 31 January 1967. This Convention deals summarily with PIL in its Articles 12 and 16.

Authorities are confronted with PIL issues: name, certificate of birth, marriage, divorce, parent child relationships. The urgency of finding adequate solutions cannot be denied.

\section{UK Case Law}

A step forward in UK law, one would say, was recently made by a High Court judge, Mr Justice Williams, in the Family Court, in a judgment of 31 July $2018 .{ }^{56}$ Petitioner was a Mrs Nasreen Akhter, respondent a Mr Mohammed Shabaz Kahn. The Attorney General intervened on invitation by the judge as 'wider public interests' were

\footnotetext{
55 [2000] OJ L 303/16.

56 [2018] EWFC 54, case no. ZC16D00278.
} 
involved. He was the '1st Interested Party'. An Islamic wedding ceremony called Nikah took place in London in December 1998. It was never followed by a civil marriage in spite of the wife's continuous pressure. They lived together as a married couple for 18 years, had four children and were publicly considered to be spouses.

Extensive case law warranted the conclusion not only that the marriage was not valid, not even void or voidable under the Matrimonial Causes Act 1973, but that the relationship had to be classified as a 'non-marriage'. It would mean that there could not even be a ground for a divorce petition as there was no marriage, and many benefits of marriage (issues of property, maintenance, pension sharing, variation of trusts) enjoyed even in case of a void marriage would be denied. The judge wrote a very long judgment to arrive at the conclusion that, the circumstances duly taken into account, this 'non-marriage' was rather to be classified as a void marriage in the terms of the Matrimonial Causes Act. A courageous, carefully motivated step in the direction of more flexibility in the appreciation of marriages celebrated according to religious law only. ${ }^{57}$

\section{EU Case Law}

Further to a request for a preliminary ruling, the ECJ recently gave a decision on how to interpret the scope of Regulation (EU) No. 1259/2010 ${ }^{58}$ (divorce and legal separation). ${ }^{59}$ A 'private' divorce was obtained before a religious court in a third country, i.e. the Islamic Court of Latakia (Syria). At the request of the husband his representative pronounced the divorce formula before the religious court on 19 May 2013. The court declared the couple divorced on the next day. The President of the Higher Regional Court of Munich granted the application by the (ex-)husband for recognition of the divorce. The ECJ decided that 'a divorce resulting from a unilateral declaration made by one of the spouses before a religious court, such as that at issue in the main proceedings, does not come within the substantive scope of that regulation'. One could imagine a different outcome, like the step forward made by Justice Williams.

Two recent judgments by the ECJ require some comments. ${ }^{60}$ Their relationship to PIL may not seem obvious but the subject matter is the relationship between EU law, Member State law and church law which is not necessarily State law (see Sect. 2), and to that extent may raise PIL issues.

Evangelisches Werk für Diakonie eV, a legal person according to German civil law, published, in 2012, an offer of employment in a project. The offer specified

\footnotetext{
57 Bucher (2009), no. 237.

58 [2010] OJ L 343/10.

59 ECJ 20 December 2017, Case C-372/16, Sahyouni v. Mamish, ECLI:EU:C:2017:988; IPRax 2018/2/238 case note D. Coester-Waltjen; FamRZ 2018/3/169 case note Claudia Meyer; Jessurun d'Oliveira (2018), pp. 2060-2064.

60 ECJ Grand Chamber 17 April 2018, Case C-414/16, Egenberger v. Evangelisches Werk für Diakonie und Entwicklung eV, ECLI:EU:C:2018:257; ECJ Grand Chamber 11 September 2018, Case C-68/17, IR v. JQ, ECLI:EU:C:2018:696.
} 
that membership of a protestant church was presupposed. Ms Vera Egenberger, of no denomination, applied, but was not recruited. She considered that her application had been rejected for that reason. Discrimination? The Bundesarbeitsgericht referred the matter to the ECJ for an explanation of Directive 2000/78, mentioned in Sect. 10. The ECJ holds that Member States are not free under the Directive to leave the issue of discrimination to the competence of a church court:

[...] where a church or other organization whose ethos is based on religion or belief, asserts [...] that by reason of the nature of the activities concerned [...] religion constitutes a genuine, legitimate and justified occupational requirement, [...] it must be possible for such an assertion to be the subject, if need be, of effective judicial review by which it can be assured that the criteria set out in Article 4(2) of that directive are satisfied in the particular case. (paragraph 59)

In this way the ECJ intends to strike

a fair balance between the right of autonomy of churches and other organisations whose ethos is based on religion or belief, on the one hand, and, on the other hand, the right of workers, inter alia when they are being recruited, not to be discriminated against on grounds of religion or belief, in situations where those rights may clash. (paragraph 51)

State courts have a delicate mission to accomplish. It is simplified by the burden of proof for the church:

[...] the church or organisation imposing the requirement is obliged to show, in the light of the factual circumstances of the case, that the supposed risk of causing harm to its ethos or to its right of autonomy is probable and substantial, so that imposing such a requirement is indeed necessary. (paragraph 67)

The ECJ recalls that the principle of proportionality, being one of the general principles of EU law, applies. In this way the ECJ expresses priority of EU law and Member State law over church law, a PIL decision.

In its 11 September 2018 decision, the Grand Chamber builds-no surpriseon Egenberger. It relates to a dispute between JQ, employee, a doctor and Head of the Internal Medicine Department of an IR hospital, and IR, employer. The hospital is a $\mathrm{GmbH}$, a private limited company, owned by the Catholic Church. The dispute has a Roman Catholic background. JQ was married in accordance with the Roman Catholic rite. He divorced and remarried in a civil ceremony without his first marriage being annulled, i.e. according to canon law. JQ was then dismissed in 2009. The Bundesarbeitsgericht referred the case to the ECJ.

The Court emphasizes the powers to be conferred on the Member State courts (paragraphs 43, 44, 47, 48 and 61). Again it stresses the three criteria genuine, legitimate and justified and the proportionality principle. It is for the referring court to verify whether IR has established that, in the light of the circumstances 
of the main proceedings, there is a probable and substantial risk of undermining its ethos or its right of autonomy, paragraph 60, like Egenberger paragraph 67.

\section{Conclusion}

There is some work to do. PIL cannot but take due note of the phenomenon of religious law in the increasingly frequent cases where foreign law connected either by nationality or by habitual residence or by whatever connecting factor makes it unavoidable or even appropriate to do so.

Open Access This article is distributed under the terms of the Creative Commons Attribution 4.0 International License (http://creativecommons.org/licenses/by/4.0/), which permits unrestricted use, distribution, and reproduction in any medium, provided you give appropriate credit to the original author(s) and the source, provide a link to the Creative Commons license, and indicate if changes were made.

\section{References}

Ancel B, Lequette Y (2006) Les grands arrêts de la jurisprudence française de droit international privé, 5th edn. Dalloz, Paris

Batiffol H (1956) Aspects philosophiques du droit international privé. Dalloz, Paris (Reprint 2002, with preface Lequette $\mathbf{Y}$ )

Beaumont PR (2008) The jurisprudence of the European Court of Human Rights and the European Court of Justice on the Hague Convention on Child Abduction. Collected Courses, vol 335. Hague Academy of International Law, The Hague

Bucher A (2009) La dimension sociale du droit international privé. General Course Hague Academy, Collected Courses, vol 341. Hague Academy of International Law, The Hague

Caparros E, Christians LL (2000) (eds) Religion in comparative law at the dawn of the 21 st century, at the occasion of the XV International Congress of Comparative Law, Bristol 1998. Bruylant, Brussels

Crul BJP (2017) Keizer Frederik II. Uitgeverij Omniboek, Utrecht

Foblets MC, Yassari N (2013) (eds) Legal approaches to cultural diversity. Hague Academy (Centre of Studies), The Hague

Gannagé L (2001) La hiérarchie des normes et les méthodes de droit international privé, Étude de droit international privé de la famille. LGDJ, Paris

Gannagé L (2008a) À propos de 'l'absolutisme' des droits fondamentaux. In: Vers de nouveaux équilibres entre ordres juridiques: Mélanges en l'honneur de Hélène Gaudemet-Tallon. Dalloz, Paris, pp 265-284

Gannagé P (2008b) Regards sur les compétences judiciaires exclusives. In: Vers de nouveaux équilibres entre ordres juridiques: Mélanges en l'honneur de Hélène Gaudemet-Tallon. Dalloz, Paris, pp 285-293

Gannagé L (2013) Les méthodes du droit international privé à l'épreuve des conflits de cultures. General Course Hague Academy, Collected Courses, vol 357. Hague Academy of International Law, The Hague

Gaudemet-Tallon H (2005) Le pluralism en droit international privé: richesses et faiblesses (le funambule et l'arc en ciel). General Course Hague Academy, Collected Courses, vol 312. Hague Academy of International Law, The Hague

Hamilton C (1995) Family, law and religion. Sweet \& Maxwell, London

Hecht NS, Jackson BS, Passamaneck SM, Piattelli D, Rabello AM (1996) (eds) An introduction to the history and sources of Jewish law. Clarendon Press, Oxford 
Jault-Seseke F, Pataut E (2018) Le citoyen européen et son nom. In: Hess B, Jayme E, Mansel H-P (eds) Europa als Rechts- und Lebensraum: Liber Amicorum für Christian Kohler zum 75. Geburtstag. Gieseking, Bielefeld, pp 371-384

Jayme E (1995) Identité culturelle et intégration: le droit international privé postmoderne. General Course Hague Academy, Collected Courses, vol 251. Hague Academy of International Law, The Hague

Jessurun d'Oliveira HU (2018) Het Europese Hof omarmt eindelijk het huwelijk van mensen met hetzelfde geslacht: een stap in de goede richting. Nederlands Juristenblad 28:2060-2064

Kinsch P (2004) The impact of human rights on the application of foreign law and the recognition of judgments-a survey of the cases decided by the European Court of Human Rights. In: Einhorn T, Siehr K (eds) Intercontinental cooperation through private international law: essays in memory of Peter E. Nygh. T.M.C. Asser Press, The Hague, pp 197-228

Kinsch P (2005) Droits de l'homme, droits fondamentaux et droit international privé. Collected Courses, vol 318. Hague Academy of International Law, The Hague

Kruiniger P (2014) Islamic divorces in Europe. Bridging the gap between European and Islamic legal orders. Eleven International Publishing, The Hague

Lagarde P (2013) (ed) Actes du colloque international de La Haye de 18 janvier. Pedone, Paris

Lagarde P (2015) La méthode de la reconnaissance est-elle l'avenir du droit international privé? Introductory course Hague Academy, Collected Courses, vol 371. Hague Academy of International Law, The Hague

Lequette Y (2017) Les mutations du droit international privé: vers un changement du paradigme? General course Hague Academy, Collected Courses, vol 387. Hague Academy of International Law, The Hague

Malatesta A (2009) Cultural diversity and private international law. In: Venturini G, Bariatti S (eds) Liber Fausto Pocar, vol II. Giuffrè, Milan, pp 643-657

Najm MC (2005) Beyrouth/Paris, Principes directeurs du droit international privé et conflit de civilisations, Relations entre systèmes laïques et systèmes religieux. Dalloz, Paris

Neuhaus PH (1966) Zum Kollisionsrecht des Codex Iuris Canonici. RabelsZ 30:40-53

Neuhaus PH (1983) Der neue Codex Iuris Canonici in privatrechtlicher Sicht. RabelsZ 47:502-512

Nishitani Y (2000) Mancini und die Parteiautonomie im Internationalen Privatrecht. Winter, Heidelberg

Siehr K (2004) Coordination of legal systems in private international law. In: Einhorn T, Siehr K (eds) Intercontinental cooperation through private international law: essays in memory of Peter Nygh. T.M.C. Asser Press, The Hague, pp 325-340

Sinclair D (1996) Jewish law in the state of Israel. In: Hecht NS, Jackson BS, Passamaneck SM, Piattelli D, Rabello AM (eds) An introduction to the history and sources of Jewish law. Clarendon Press, Oxford, pp 397-420

Sonnenberger HJ (2010) Anerkennung statt Verweisung? Eine neue internationalprivatrechtliche Methode? In: Bernreuther J (ed) Festschrift für Ulrich Spellenberg. Sellier, Munich, pp 371-391

Struycken AVM (2000) Le droit religieux et son application par les juridictions civiles et religieuses. Coexistence, interrelations et influences réciproques aux Pays-Bas. In: Caparros E, Christians LL (eds) Religion in comparative law at the dawn of the 21 st century, at the occasion of the XV International Congress of Comparative Law, Bristol 1998. Bruylant, Brussels, pp 417-438

Struycken AVM (2009) Co-ordination and co-operation in respectful disagreement. General course Hague Academy, Collected Courses, vol 311. Hague Academy of International Law, The Hague

Symeonides SC (2017) Private international law: idealism, pragmatism, eclecticism. General course Hague Academy, Collected Courses, vol 384. Hague Academy of International Law, The Hague

Vermes G (2012) Christian beginnings, from Nazareth to Nicaea AD 30-325. Pinguin Books, London

Von Savigny FC (1849) System des heutigen Römischen Rechts, Achter Band, Drittes Buch: Herrschaft der Rechtregeln über die Rechtsverhältnisse. Berlin

Vonken APMJ, Ibili F, Schols FWJM (2016) Mr. C. Asser's handleiding tot de beoefening van het Nederlands burgerlijk recht, Asser 10-II: Internationaal privaatrecht, Internationaal personen-, familie- en erfrecht. Kluwer, Deventer

Ware T (2015) The orthodox church, an introduction to Eastern Christianity. Pinguin Books, London

Wengler W (1991) Kollisionsfragen im katholischen Kirchenrecht. Zeitschrift für Rechtsvergleichung 1:26-28 